\title{
Regional Potentials in the Border Region Austria-Slovakia: The Project "Regiogoes" Reveals New Settlement and Housing DeVelopments
}

\author{
Johannes HUEMER and Vera KAPELLER, both Vienna [Wien]*
}

with 9 figures in the text

\section{Content}

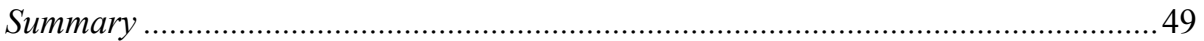

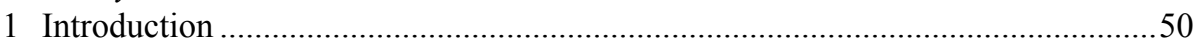

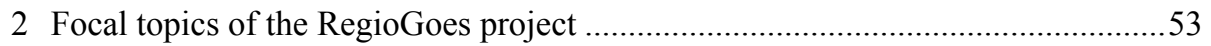

3 Current and future housing development in the border region

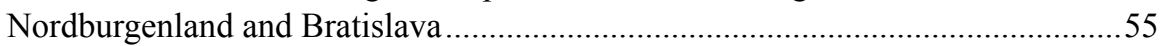

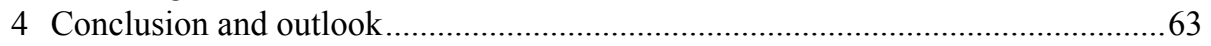

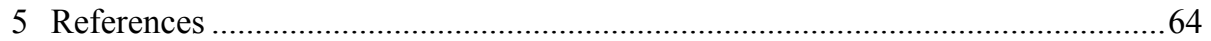

\section{Summary}

The border region Nordburgenland-Bratislava is part of the city region of Vienna [Wien] and the city region of Bratislava (or the region Vienna-Bratislava), and is a region of high growth dynamics in terms of both economic and population development. The tasks and aims of the project RegioGoes are to analyse the settlement-and housingspecific development potentials of this border region and, based on this, to develop proposals for action regarding practical planning. The population and housing analyses will provide a basis for discussing the current and future settlement and housing development in this border region. An important component of this research approach will be to document and publicise the architectural cultural heritage. Recommendations on re-use and revalorisation of existing buildings in the Nordburgenland town centres and specific architectural designs will ultimately provide new solutions.

* DI Johannes Huemer, Vera KAPELLER, PhD., both Institute of Urban and Regional Research, Austrian Academy of Sciences, Postgasse 7/4/2, A-1010 Wien, Austria; email: johannes. huemer@oeaw.ac.at; vera.kapeller@gmail.com 


\section{Introduction}

Given developments throughout history and cultural landscapes with different characteristics, the border region of Nordburgenland and Bratislava has many commonalities and many contrasts. It is important to note that there are two different government and settlement systems colliding in this region. Predominantly agricultural Nordburgenland borders directly on the Slovakian capital Bratislava. The entire city region of Bratislava is currently confronted with a dynamic wave of suburbanisation: The associated increase in construction activities in this region, and their effects and consequences for Nordburgenland, were items of focus for the cross-border European Union (EU) project "RegioGoes - Regional potentials in the border region Austria-Slovakia".

\subsection{The problem}

The border region Nordburgenland-Bratislava is part of the city region of Vienna [Wien] and the city region of Bratislava (or the region Vienna-Bratislava), and is a region of high growth dynamics in terms of both economic and population development. Overall, the entire east region of Austria (Vienna, Vienna environs and Nordburgenland) is predicted to undergo dynamic population growth until 2030 (FAssmann, Görgl \& HelBich, pp. 67ff.; ÖROK 2015). According to these projections, population growth in Nordburgenland will be attributable above all to migration away from the large metropolises Vienna and Bratislava (Fassmann, Görgl \& Helbich, pp. $67 \mathrm{ff}$.). The city region of Bratislava is currently confronted with a dynamic wave of residential suburbanisation. The outskirts and environs of Bratislava are undergoing extensive housing construction activities. The ensuing relocation of housing and migration of labour have already exceeded the Slovak-Austrian border several years ago. Demographic and economic development in neighbouring Nordburgenland, however, is more difficult. Besides those municipalities with a dynamic growth structure - in terms of population, trade, economy and housing construction activity, above all in the north of the region - there are also municipalities with structural problems such as a high elderly population and a problematic economic structure (Seewinkel).

Common to the regions on either side of the Slovak-Austrian border is that the new construction activity - for industry, trade and housing purposes - is taking place predominantly on the village/city outskirts. This has resulted in greater space requirements and a higher volume of traffic. Such developments are already familiar

\footnotetext{
1 The project was conducted between January 2013 and March 2015 as a cooperation between the Institute of Urban and Regional Research of the Austrian Academy of Sciences, the Faculty of Architecture of the Slovak University of Technology Bratislava, Regional Management of Burgenland and the municipality Zurndorf/District Neusiedl am See, and was funded by the Cross-Border Cooperation Programme Slovakia-Austria 2007-2013.
} 
from large and medium Anglo-American and European cities. The town centres of many municipalities in Nordburgenland have a high vacancy rate, since those people interested in new buildings, including many young families, prefer to live in a new building on the town outskirts. Domiciles in the town centre remain vacant, while small businesses and inns have closed down as customers drive instead to the large shopping and speciality centres on the town outskirts. Given the general lack of public transport, a car is indispensable.

Figure 1: Single-family housing in Nordburgenland (Photo: Vera KAPELLER 2015)

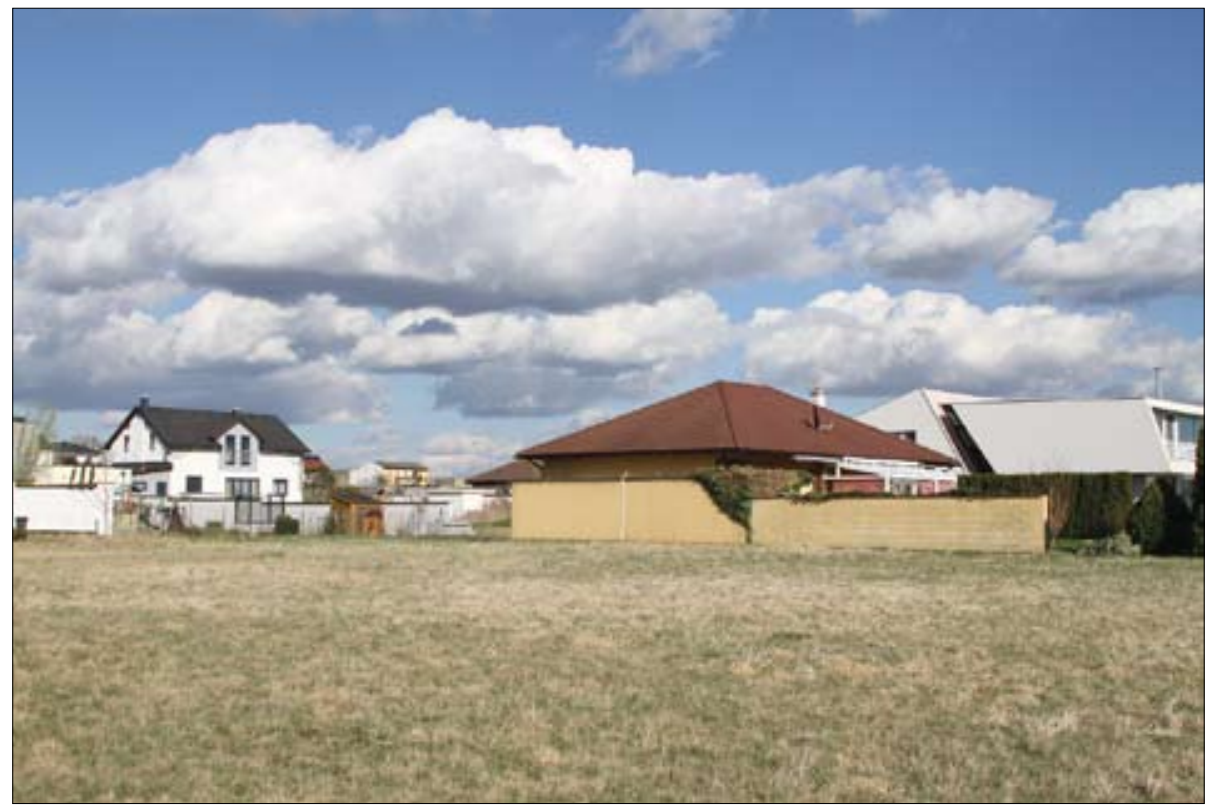

The project "RegioGoes", which deals with the effects of these developments primarily in the area of housing construction development, therefore asks important questions: How are these dynamic, sometimes opposing developments affecting the traditional rural settlement and housing structures and lifestyles in Nordburgenland? What are the consequences of population growth, on the one hand, and an aging population, on the other, on current and future housing construction activity? How can one help to revive the town centre with new functions and housing concepts? How can new ideas for cohabitation in the town centres contribute to social and generationappropriate coexistence? Where and what forms of buildings and housing should be constructed in this valuable cultural landscape between the Danube [Donau] and Lake Neusiedl [Neusiedler See, Fertö], with numerous scenically unique small regions (for example the World Heritage Site Lake Neusiedl)? What problems, and what opportunities do the new developments bring with them for the border region? 


\subsection{Tasks and aims}

The tasks and aims of the project RegioGoes are therefore to analyse the settlementand housing-specific development potentials of the border region Bratislava and Nordburgenland and, based on this, to develop proposals for action regarding practical planning. As a basis for this, it is important to promote the attractiveness of this region, to strengthen its architectural heritage and to develop identity-defining structures that can increase the quality of life and living conditions. This would be implemented in existing structures and on building development sites as energetically and ecologically optimised forms of housing. Enhancing and publicising the architectural cultural potential in this border region is an important aim of the project.

These tasks will be handled according to several research priorities: Investigations of the development in forms of settlement, construction and housing in the border region and analyses of the demographic data form the basis for developing new housing construction concepts. Statistical data have been interpreted, existing housing analysed and comprehensive on-site investigations conducted on the existing buildings. Furthermore, significant monuments in the architectural culture were documented as another research priority and presented in a separate publication (KAPELLER \& ROMANKO 2015).

The aim of the "RegioGoes" project is to find alternatives to the current growth trend on the outskirts by increasing attractiveness, functionality and social cohesion in the town centre. On this basis, new functions will be developed for old building structures - vacated town centres and unused structures - and housing models developed for various age and social groups. In the Nordburgenland towns, it is important, among other things, to examine firstly the current growth trends on the town outskirts, and secondly the often underused existing buildings in the town centre.

\subsection{The area under investigation}

The area under investigation lies in the middle of "Centrope", the Central European Region, one of the most dynamic living areas in Europe, with just over six and a half million inhabitants (CENTROPE 2012, p. 4). It is situated in the border triangle Austria-Slovakia-Hungary. The area of investigation includes, on the Slovak side, the boroughs of the capital city Bratislava (Devínská Nová Ves, Devín, Karlova Ves, Petržalka, Jarovce, Rusovce and Čunovo) and, on the Austrian side, the District Neusiedl am See with a total of 27 municipalities. To the east, the area of investigation borders Hungary, to the northwest the State of Lower Austria [Niederösterreich]. As part of the former Hungarian County Moson/Wieselburg, the Burgenland part was closely associated with the history of this county until 1921, while the places belonging to Bratislava were in the County of Pozsony/Pressburg. The neighbours on the southeast 
bank of Lake Neusiedl are the Burgenland municipalities of the Eisenstadt-Umgebung District.

Figure 2: Location of the area of investigation (Graphics: ISR 2016)

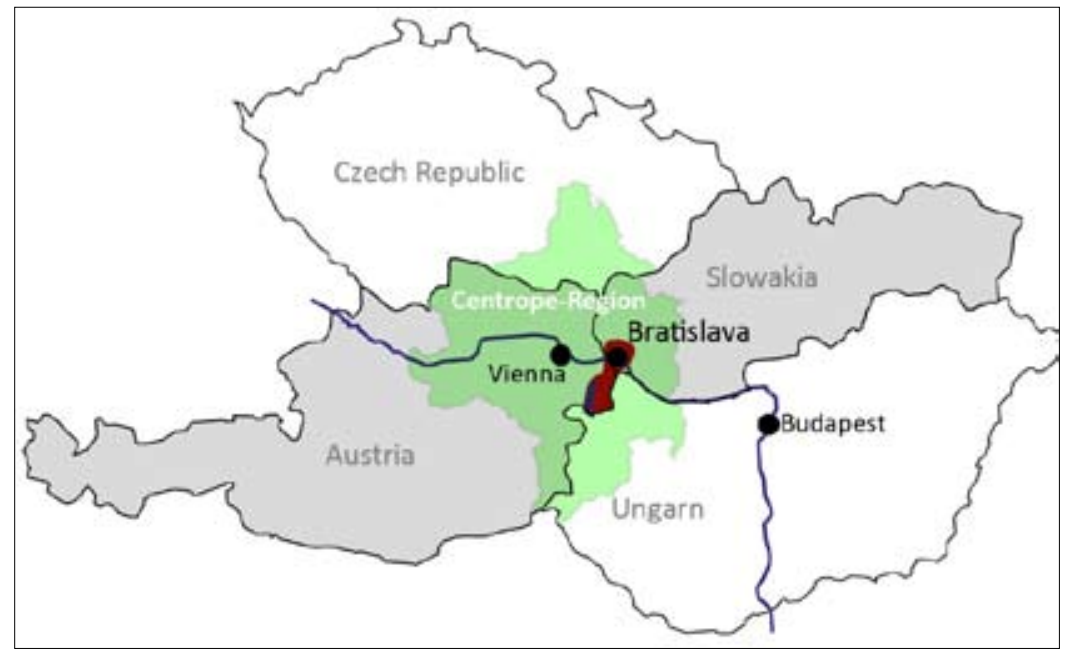

Despite the central location in the heart of Europe, this region was destined to lead a marginal existence for a long time. When the Iron Curtain closed after the Second World War, Burgenland, and thus the District Neusiedl am See with it, became a remote geographical location.

\section{Focal topics of the RegioGoes project}

The RegioGoes project is founded on four main focal topics:

(1) Comprehensive analysis of population and housing

(2) Documentation and publication of the architectural cultural heritage

(3) Studies on re-use and restoration of existing buildings

(4) Public relations work, informational campaigns and travelling exhibition

In the first part of the project, a comprehensive analysis was conducted of the population and housing. Working from the extensive material, comprising statistical data, historical map material, aerial photographs and numerous studies, a fundamental investigation was prepared. The most important findings from this are summarised 
in the publication "Aktuelle und zukünftige Wohnbauentwicklung im Grenzgebiet Nordburgenland und Bratislava" (Current and future housing development in the border region Nordburgenland and Bratislava) (KAPELLER \& Huemer 2015a).

The second point of focus of the project was to document and publicise the architectural cultural heritage of the region. One essential aim of the project was to recognise the attractiveness of the border region Nordburgenland and Bratislava and subsequently to promote it by making a broader public aware of the special character of the region, especially in an architectural cultural sense. For further developing the regional, partly agricultural building structures, it is therefore indispensable for the public to gain an appreciation of the architectural cultural heritage. Especially that which is considered unexceptional at present because it "has always been there" is what makes the region special. Building upon existing analyses of the regional construction and housing culture (MAYER 1993), the historical forms of construction and settlement were accordingly worked out in detail. The region between the Leitha, the Danube and Lake Neusiedl is associated with a long administrative, sociographic and architectural history. The historical buildings are visible testimony to a common architectural and residential culture in the border area. Two of the essential subjects of architectural cultural history are summarised in a separate publication: Firstly, Roman history and its architectural testimony is recounted under the title "Wir sind die Römer. Auf den Spuren der Römer im westlichen Teil der römischen Provinz Pannonien und der Villa Rustica" (We are the Romans. Retracing the footsteps of the Romans in the western part of the Roman province Pannonia and the Villa Rustica). Secondly, the most important buildings of the Middle Ages are presented, such as forts and castles (KAPELLER \& Rомако 2015). By highlighting remarkable architectural cultural monuments, the project ought to contribute towards creating a common identity-establishing sense of belonging in the context of the architectural culture on both sides of the border.

Building on the two abovementioned focuses, several feasibility studies were subsequently developed on the topic of continued use and restoration of settlement structures or underused existing buildings. On the Slovak side, the central themes were remodelling of the town centre and architectural designs for new forms of buildings and housing in Devínska Nová Ves, a northern borough of Bratislava. Together in a two-semester design seminar, students of the Faculty of Architecture of STU Bratislava worked on implementation studies and architectural studies in selected locations of the borough. The aim here was to develop new housing models for various social groups in Devínska Nová Ves. The results of the design work and research methods were presented in the publication "Nové modely bývania/New housing models" (BACOVÁ, PušKÁR \& VRÁBLOVÁ 2015).

On the Austrian side, in the Nordburgenland Municipality Zurndorf, District Neusiedl am See, concepts were developed for re-utilising region-typical plots and "Streckhof"-style homes. In the interest of promoting cross-border cooperation, as well as collaboration between architecture, spatial planning, research and teaching, a team of architecture students from each of the STU Bratislava and TU Wien were 
invited to develop suggestions, concepts and designs in a term paper. The Municipality Zurndorf is a growing municipality, however the current growth developments are almost exclusively limited to the outskirts, while underused and even completely vacant buildings are observed in the centre. The morphology of the elongated, narrow plots in the town centre presents a particular challenge for use as housing nowadays. This means strategies are needed for making good use of the historically developed building structure, so that their use is still possible despite changing lifestyles. The resulting projects thus reveal various development potentials and visions for Zurndorf. The strategies draw on various measures and interventions: from new planning guidelines and incentive systems for certain plot developments to models for appropriation and self-organisation. All of these approaches attempt to offer action proposals for a new planning practice that restores the town centre to its original position: at the centre!

The travelling exhibition "Neue Funktionen für alte Baustrukturen" (New functions for old building structures) is aimed at the municipalities and general public in the entire region of Nordburgenland and Bratislava. The aim of the exhibition was to display the concepts and ideas for the old building and settlement structures in the form of posters to a wide public and thus to show all the different possibilities for re-use (KAPELLER \& HUEMER 2015b). When it comes to re-using underused buildings in particular, especially in central locations, an extremely sensitive approach must be taken and most of the owners are barely coping with the existing building situation. In various discussions with those concerned, it was repeatedly stated that they hardly know what to do with the existing buildings or basically what options they would have. It seemed appropriate, therefore, to present the individual projects to the public not only in the respectively involved places, but moreover to present this multitude of possibilities for re-use to all municipalities in the region. Since they were dealing with regional-typical divisions of land, apportionment to other municipalities is perfectly acceptable and elaboration of the material creates an added value.

\section{Current and future housing development in the border region Nordburgenland and Bratislava}

The analyses of the settlement and housing development and the demographic, social and economic data in the border region form the basis for developing new settlement and housing concepts in the border region.

The problem of residential suburbanisation is therefore studied using the example of the region Bratislava-Nordburgenland (KAPELLER 2015, pp. 23-35). These are similar phenomena to those we are familiar with for several decades from the environs of big cities - known variously as 'fat belts' or 'outskirts' etc. (MAYER 2004). Despite many negative effects of these urban expansions, the city of Bratislava has still hardly learnt from these global developments to date. A lack of concepts for public space design, 
inadequate infrastructure, numerous large-area shopping centres, inadequate means of public transportation and a subsequent increase in personal motorised traffic now characterise the outskirts of Bratislava (VITKOVÁ 2015, pp. 83-93). The only attempts to counter any undesirable developments here were made in the two European Union (EU) projects BAUM - Bratislava Umlandmanagement/Bratislava Urban Regional Cooperation, and CIDEP - Forms of housing schemes for urban expansion (KAPELLER \& HUEMER 2015a, 11ff.; MA 18 2001). The BAUM project, in particular, deals with the effects of the urban development of Bratislava on the Austrian bordering municipalities in Lower Austria and Burgenland (AdAmová 2011; SCHAFFER et al. 2014).

The peripheral situation on the Slovak and Hungarian border has greatly influenced the infrastructural, economic and demographic development of Nordburgenland. The municipalities of the District Neusiedl am See, for example, have recorded very different growth and shrinkage dynamics over recent decades (Kapeller, Huemer \& BRAUN 2015, pp. 37ff.). Alongside strong population growth in the northern part of the district, the municipalities in the south, between Lake Neusiedl and the Hungarian border (Seewinkel) are experiencing high population losses (see Fig. 3).

\section{Figure 3: Population development 2001-2011 in the area of investigation}

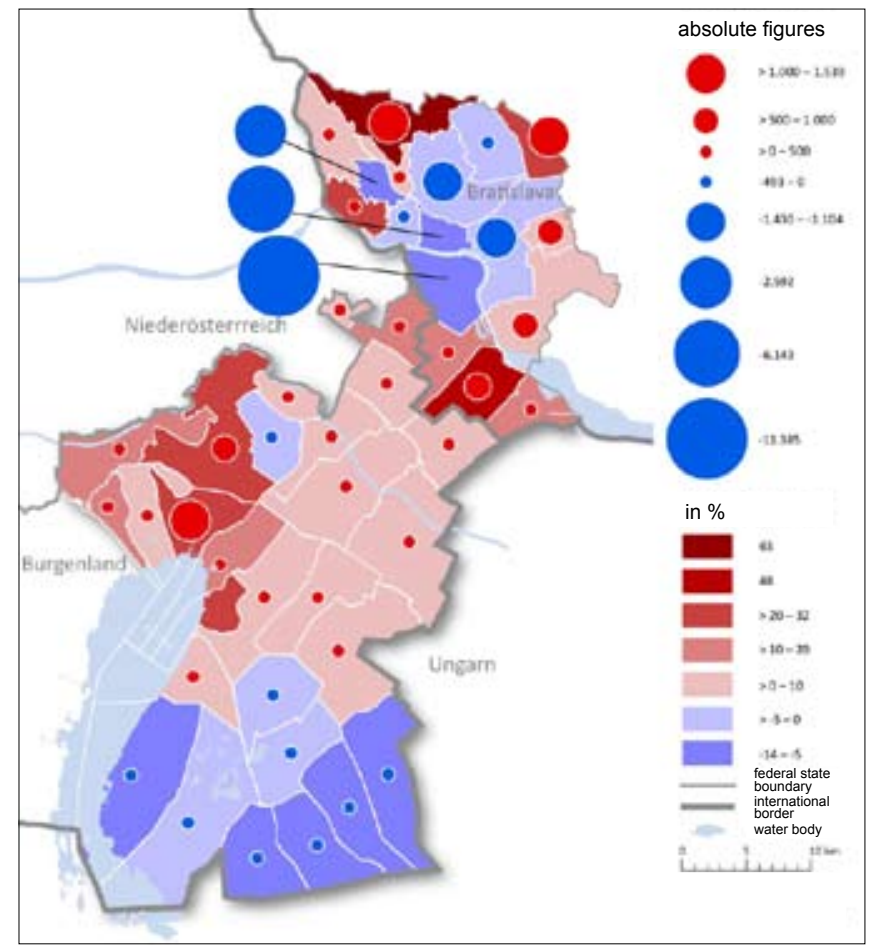

Sources: Statistik Austria, Statistical Office of the Slovak Republic 
Firstly, the population increase in the northern part over the past two decades is attributable to the development of the transportation infrastructure (motorway, rail) (KAPELler \& Huemer 2015a, pp. 20f.). Secondly, however, given better accessibility, expanding suburbanisation in the two nearby capital cities Vienna and Bratislava is leading to an increasing population in the north of the District Neusiedl am See. On the Slovak side of the area of investigation, the population increase over the years 2001 to 2011 was essentially concentrated on the outer boroughs of Bratislava, while the central area of the city was confronted with a population decline. The borough Petržalka, with the largest prefabricated estates in Central Europe (KAPELLER 2009) recorded a strong decline in population by 11,385 people, while the southern boroughs of Bratislava (Čunovo, Jarovce, Rusovce) all underwent strong population growth. The following chart (Fig. 4) illustrates the fact that the Slovak population is not only settling on the fringes of the city of Bratislava, but is also crossing the border to Austria.

Figure 4: Balance of migration of Slovak citizens

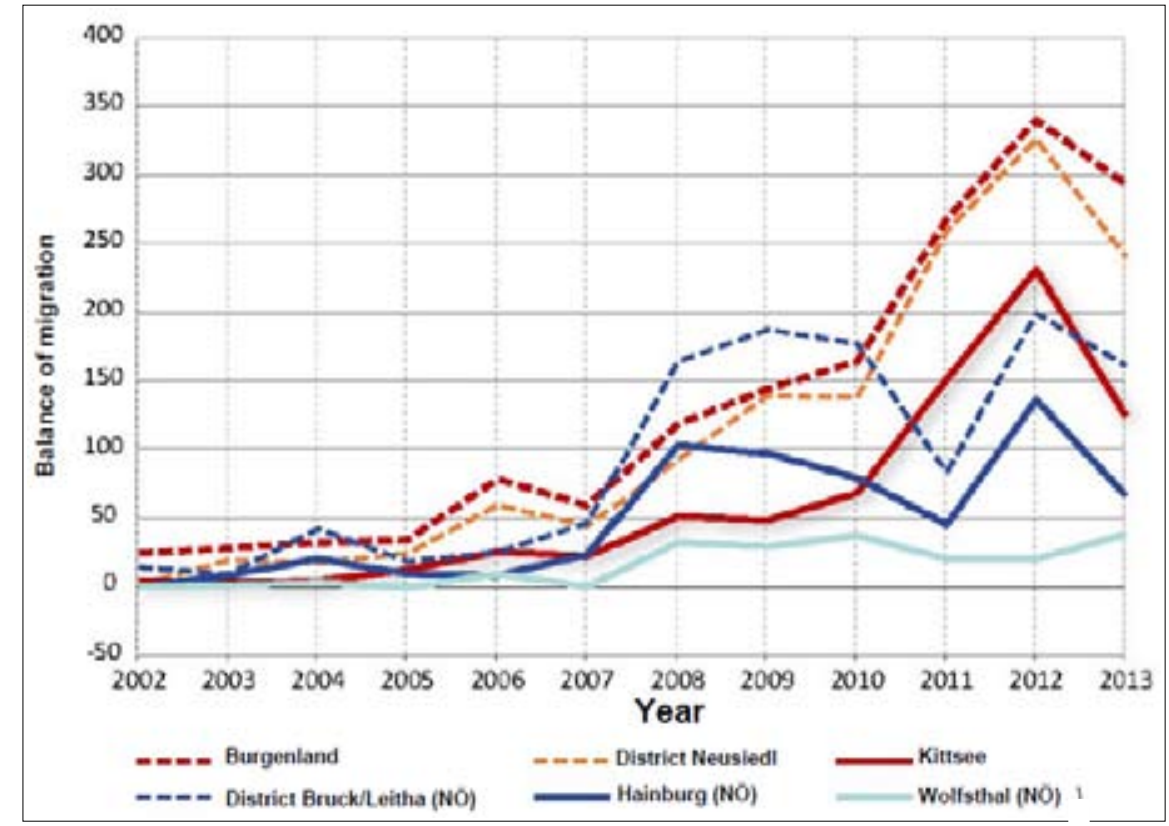

Source: StATISTIK Austria

The Municipality Kittsee, which directly borders Bratislava, has been experiencing a strong influx of Slovak citizens since the mid-2000s. A good fifty per cent of all influx is from Slovakia (KAPELLER, HuEMER \& BRAUn 2015, pp. 43f.). In the period from 2007 
Figure 5: Population projection for the District Neusiedl am See, Burgenland and Austria 2015-2050 (a: Map, b: Diagram)

Figure 5a: Map

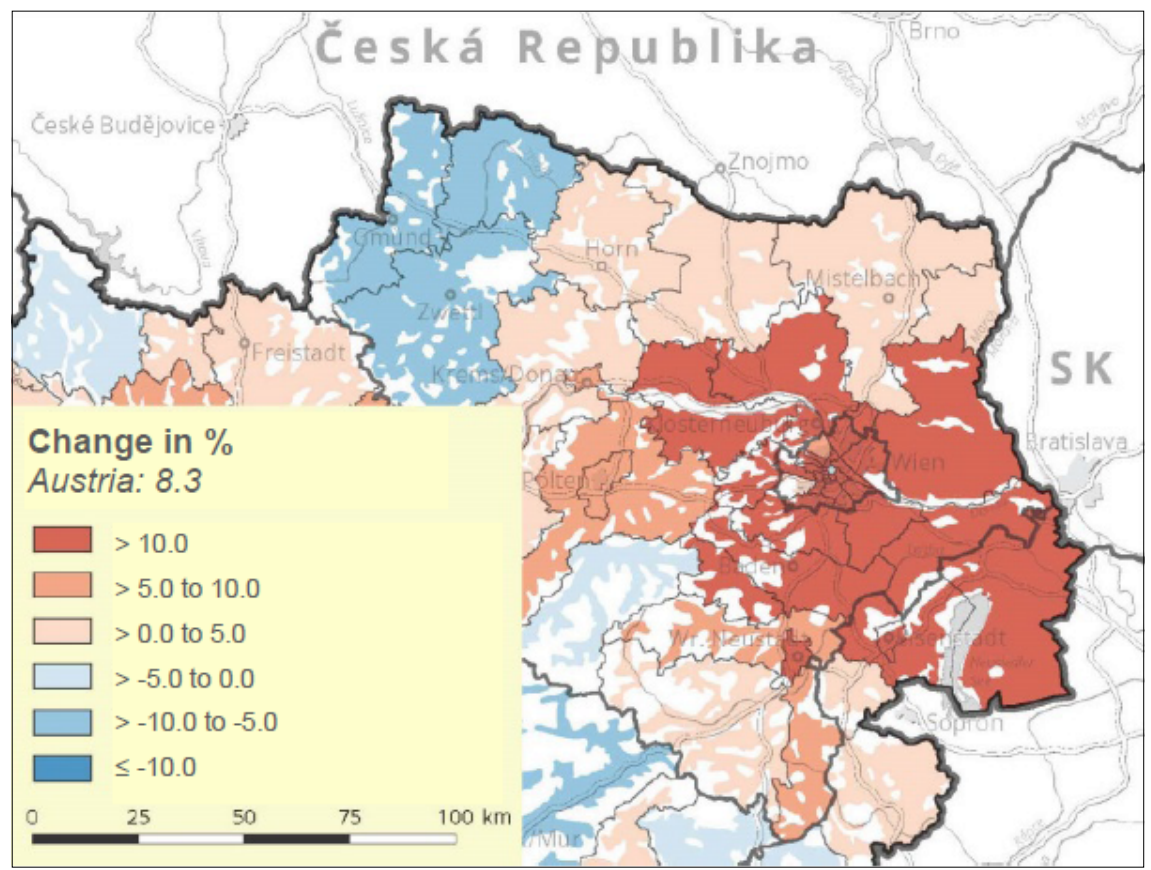

Figure 5b: Diagram

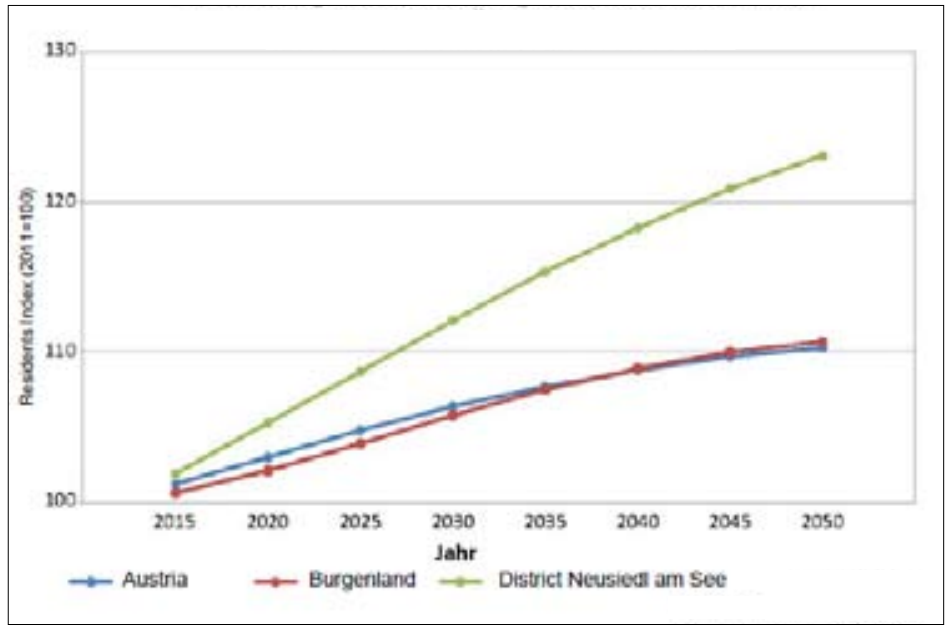

Source: StatistiK Austria, ÖROK 
to 2012, a total of 732 people moved from neighbouring Slovakia to Kittsee. Together with internal migration of nearly $50 \%$, mostly from the surrounding municipalities, the Municipality Kittsee has been one of the strongest growing municipalities of Austria since 2012.

According to the projections for population development by 2050, the population of the District Neusiedl am See will consequently increase greatly (ÖROK 2015) and far exceed growth rates of Burgenland or Austria (Fig. 5). This shows the necessity for a strategically controlled approach to future settlement development.

The contrast between urban and rural strongly defines the character of the border region Bratislava-Nordburgenland (KAPELLER 2015, pp. 26f.). This is seen not only from the lower population density in Nordburgenland, but also in the current trend towards the single-family building, which has continued steadily over decades. According to Statistik Austria, in 2011, the percentage of single- and two-family buildings among all buildings in the District Neusiedl am See was a little more than $91 \%$, and was thus the highest percentage in Austria. It is not without reason that Burgenland is referred to as the "state of the homebuilders". A similar figure is seen for the District Neusiedl am See as well (Fig. 6).

Figure 6: Percentage of buildings with 1 or 2 residential units among all buildings, 2011

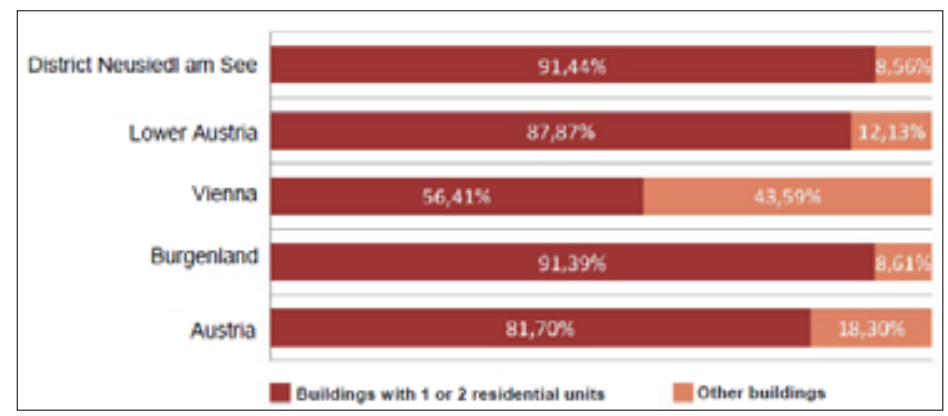

Source: Statistik Austria

A look at the distribution of buildings with one to two residential units furthermore shows that the municipalities of the district in the border area, and in particular the border of Hungary, have greater percentages of single-family buildings (buildings with one to two residential units) than those, for example, towards Lake Neusiedl. Peak values higher than $95 \%$ (e.g. Municipality Halbturn) are not uncommon among the municipalities on the Hungarian border (KAPELler \& Huemer 2015, pp. 55f.) (Fig. 7). 
Figure 7: Buildings with 1-2 residential units, 2011, absolute and relative figures

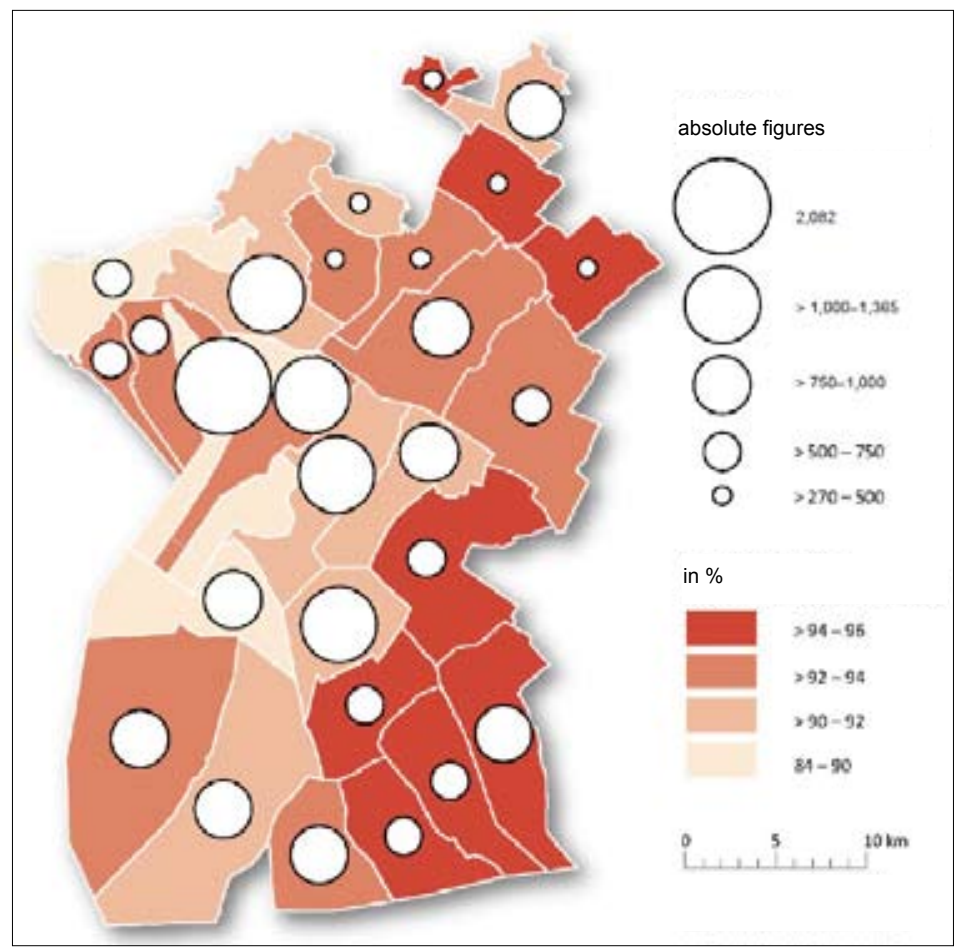

Source: STATISTIK Austria

Those municipalities of the District Neusiedl am See that were confronted with a population decline in the last decade and which are primarily in the southern part (Seewinkel), also have a higher percentage of buildings with one or two residential units. A comparison of the communities in relation to population and housing development in the period of 2001 to 2011 clearly shows the development trends of these municipalities. In all municipalities with a declining population, however, varying degrees of housing construction activity are observed (Fig. 8). This ultimately leads to an increase in underused apartments and buildings in these places, as well as an increase in vacancies in the centres. This in itself indicates that there is a great need for action in the future. 
Figure 8: Housing and population development from 2001 to 2011 in selected municipalities of the District Neusiedl am See

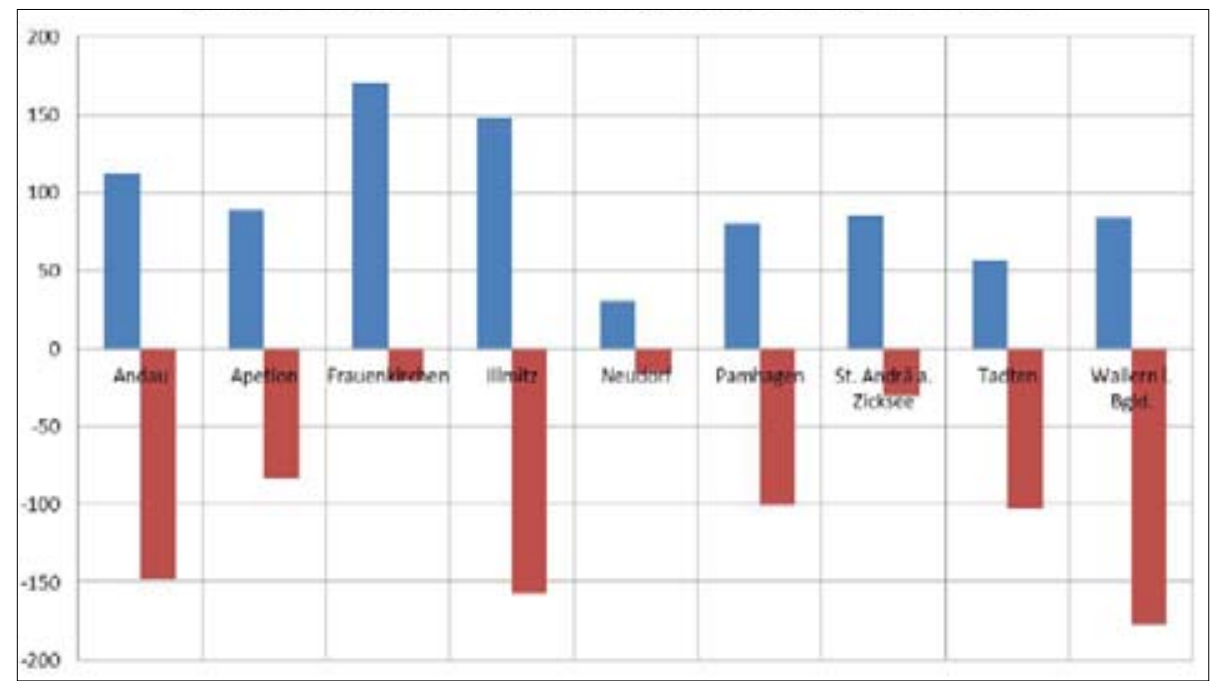

Source: Statistik Austria

At the same time, however, during recent years, a certain trend reversal has been observed in the District Neusiedl am See, as a look at the number of subsidised apartments that have been financially supported by the Burgenland Housing Fund shows. While before the turn of the millennium the single-family building was the most funded form of housing in the district, starting from the mid-2000s, the construction of subsidised apartment buildings with more than three residential units increased significantly. Here, it can be seen that particularly those municipalities in the area of influence of the two capital cities Vienna and Bratislava, and therefore those with good transport connections, have built increasing numbers of urban housings in the form of apartment buildings. Ultimately, this trend goes so far that multi-storey apartment blocks have already been built in all 27 municipalities of the district, including in those facing a population decline (Fig. 9). Basically, the trend towards denser forms of housing is quite laudable, however, it must be noted in this context that the new buildings of the mostly local housing cooperatives have been built predominantly on the outskirts of the respective municipalities, which ultimately greatly supports the negative development of the (vacant) town centres. 
Figure 9: Number of subsidised residential units in the District Neusiedl am See in the period 2000-2012

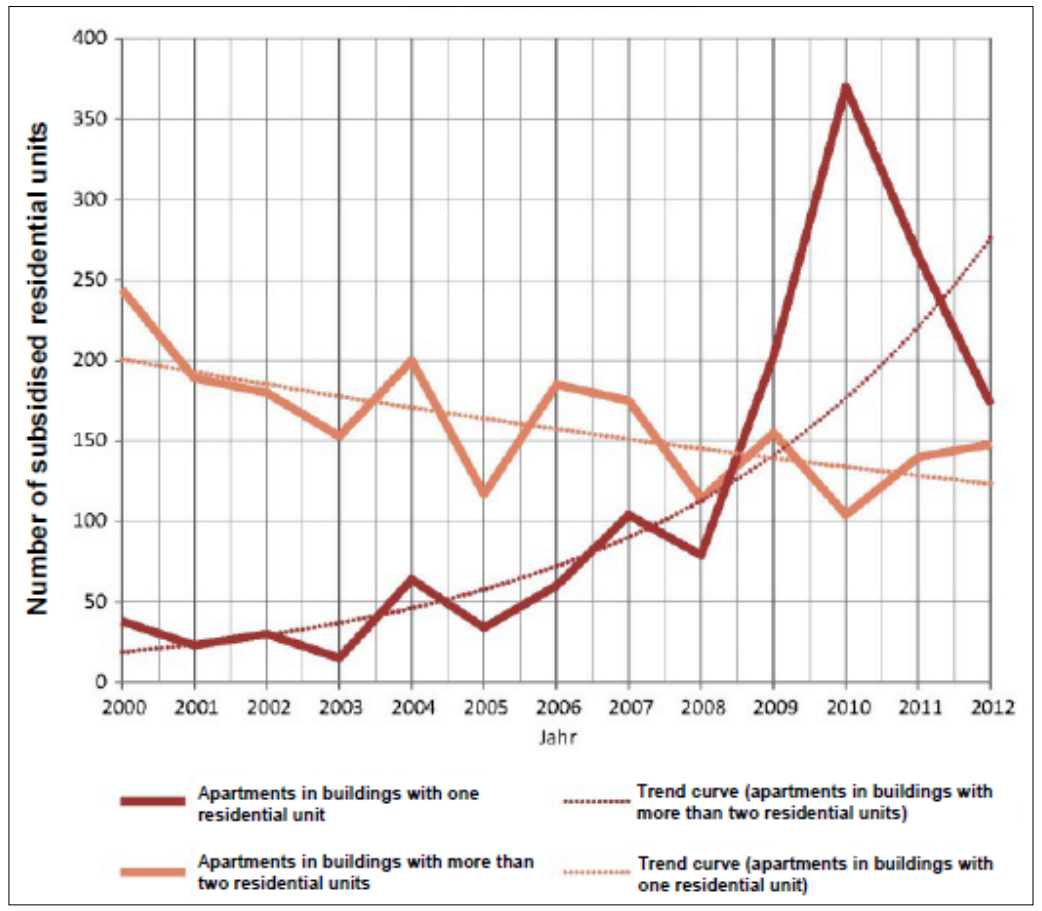

Source: Amt der Bgld. Landesregierung LAD-RO-WBF; Burgenland Housing Subsidy 2013

All Nordburgenland municipalities have in common that the new housing construction activity, of single-family houses and apartment buildings alike, is concentrated almost exclusively on the outskirts, while numbers of underused and vacant buildings are increasing in the centre (KAPELLER \& HUEMER 2015c, pp. 55ff.).

The aim is to find realistic alternatives to the currently ongoing growth trends on the outskirts. This should be done by increasing attractiveness, functionality and social cohesion in the town centres (KAPELLER \& Huemer 2015d, pp. 95ff.). One way to reach this goal is to create new functions for the old, existing building structures - i.e. vacated town centres and unused structures - and in this context to develop new housing models for various age and social groups. It is therefore essential for the municipalities to be clear of their own actions: Whom are we building for? How do we cope with the demographic trend towards an aging population in social housing? What and where should we build: exclusive versus social - housing in lakeside parks versus housing for young families and seniors? 
Based on this, architectural designs were developed in cooperation with architecture students from Vienna and Bratislava and from the Nordburgenland Municipality Zurndorf (KAPELleR \& Huemer 2015b). In their drafts, the students are working on re-using old building structures in the village centre. Working from the example of a typical elongated property owned by the municipality, questions were investigated on handling gaps between buildings, old and new buildings, connections to existing structures and inner-city networking. The works show many examples of development potentials and visions for the typical village-centre structures in the region and present various options for using the elongated plots in the village centre. It became clear that the term housing offers a lot of latitude and the projects are aimed at a very broad spectrum of users. From starter apartments for young people from the village to socially acceptable housing for young families, to retirement homes or assisted-living apartments, it was attempted to find a form of building for a crossgenerational community in the village centre. This is important because a high demand for affordable 'starter apartments' exists, especially in recent years and not only in Burgenland. Furthermore, the municipal representatives repeatedly pointed out that attempts are currently being made to offer building plots at low prices to provide young village residents with affordable plots, but that, at present, this is mostly only possible at newly dedicated locations on the outskirts. Dense development and reuse of centrally located plots therefore presents a possible starting point for 'young housing in the town centre'. Another outcome is that generation living, with young and old living in the town centre, can represent a return to the original idea of life in the town. Living in the village centre allows the older population, in particular, to remain in familiar surroundings and not to have to move to the outskirts, into the assisted-living apartment complexes and/or retirement homes that have been built in many places recently, or even have to move to a new municipality at an advanced age because there is no longer any suitable housing for the elderly in their home town. In these cases, however, it is necessary to develop new instruments in order to activate the underused or vacant building sites, and build or rebuild on them in the sense of circular flow land use management.

\section{Conclusion and outlook}

In many respects, it is desirable for the rural character of this unique cultural landscape in the border region between the Danube and Lake Neusiedl to be conserved. In the region of Bratislava, the many new buildings on the much-cited 'green field' can hardly be considered favourable. Housing estates isolated from the town centre and built near ponds or in scenically exposed locations in the border area, where they negatively impact the landscape character, must be contested. Therefore, in future, new housing estates on the outskirts and environs of Bratislava and in the Nordburgenland 
municipalities should be planned as close as possible to the compact built-up area so that they can be connected to the existing local infrastructure. In those municipalities where the percentage of subsidised multi-storey apartment blocks is significantly increasing, architecturally appealing and landscape-suitable housing concepts should be realised. In the sense of creative, social, environmentally sound and in the future cross-border housing development, this could also mean that innovative housing construction projects - social housing for young families and innovative housing for older generations - will bring an entirely fresh image to this border region. Furthermore, it could create an economic added value, e.g., by forcing and expanding the tourism industry. It must be this border region's aim to maintain the cultural landscape in its entirety. This means never allowing the town outskirts to be blocked in by illconsidered, short-term construction projects of any kind - referring not only to the housing sector but also to the construction of low-cost 'shopping paradises'. Both in Nordburgenland and in the border regions of Bratislava, the primary aim is to revaluate the compact town centres with new functions and forms of construction.

The settlement and housing developments in the city (Bratislava) and the environs (Nordburgenland) can no longer be looked at separately, since they are and will always be directly linked to each other. A lively regional awareness must therefore be raised in the form of cross-border cooperation. This, however, will first require dedicated and honest cooperation, not only on paper, for this cross-border region. Consideration must be given to more than merely the economic-functional qualities of the border region. Well-reasoned infrastructural measures and resolutions for issues of quality of life and living with respect to maintaining the intact cultural landscape are therefore the order of the day. These measures ultimately play an important role not only for the population, but also for the rating of the economic region of Vienna-Bratislava (car industry and petrochemicals in Slovakia; tourism, wellness and wine business in Nordburgenland). A coordinated approach to this problem is needed, where the aim is to reposition this unique cultural landscape between the Danube and Lake Neusiedl, and its population, in a unified Europe based on their qualities and development potentials.

\section{References}

AdAMCovÁE. (2011), Harmonisierte Informationsbasis. BAUM-BratislavaUmlandmanagement. $<$ http://www.projekt-baum.eu/de/vismo/dokumenty2.asp?id_org=700029\&id=1008> (accessed 18 March 2016)

Bacová A., Puškár B., Vráblová E. (2015), Nové modely bývania. Neue Wohnmodelle. Praha, Gasset.

CENTROPE (2012), Central European Region. <http://www.itas.fzk.de/deu/Itaslit/joua99a. pdf $>$ (accessed 18 March 2016) 
Fassmann H., Görgl P., Helbich M. (s.a.), Atlas der wachsenden Stadtregion. Materialienband zum Modul I des Projekts "Strategien zur räumlichen Entwicklung der Ostregion (SRO)". Wien, Planungsgemeinschaft Ost (PGO).

KAPELLER V. (ed.) (2009), Plattenbausiedlungen. Erneuerung des baukulturellen Erbes in Wien und Bratislava. Stuttgart, Fraunhofer IRB Verlag.

KAPELLER V. (2015), Bevölkerungs- und Siedlungsdynamik im Grenzgebiet Nordburgenland und Bratislava. In: KaPeller V., Huemer J. (ed.), Aktuelle und zukünftige Wohnbauentwicklung im Grenzgebiet Nordburgenland und Bratislava, pp. 23-35. Wien, Institute of Urban and Regional Research.

KAPElLer V., Huemer J. (eds.) (2015a), Aktuelle und zukünftige Wohnbauentwicklung im Grenzgebiet Nordburgenland und Bratislava. Wien, Institute of Urban and Regional Research.

Kapeller V., Huemer J. (eds.) (2015b), Neue Funktionen für alte Baustrukturen. CD zur Wanderausstellung. Wien, Institute of Urban and Regional Research.

Kapeller V., Huemer J. (2015c), Bauliche Strukturen im Bezirk Neusiedl am See: vom Steildachhaus über den Bungalow bis zum Passivhaus. In: KaPeller V., Huemer J. (eds.), Aktuelle und zukünftige Wohnbauentwicklung im Grenzgebiet Nordburgenland und Bratislava, pp. 55-82. Wien, Institute of Urban and Regional Research.

Kapeller V., Huemer J. (2015d), Zukünftige Siedlungs- und Wohnbaupotentiale. In: Kapeller V., Huemer J. (eds.), Aktuelle und zukünftige Wohnbauentwicklung im Grenzgebiet Nordburgenland und Bratislava, pp. 95-107. Wien, Institute of Urban and Regional Research.

Kapeller V., Huemer J., T. Braun T. (2015), Statistische Grundlagen zur Bevölkerung in den Gemeinden des Bezirks Neusiedl am See. In: Kapeller V., Huemer J. (eds.), Aktuelle und zukünftige Wohnbauentwicklung im Grenzgebiet Nordburgenland und Bratislava, pp. 3744. Wien, Institute of Urban and Regional Research.

Kapeller V., Romako M. (2015), Auf den Spuren der Vergangenheit in der Grenzregion Nordburgenland und Bratislava. Villen - Burgen - Schlösser. Wien, Institute of Urban and Regional Research.

Magistratsabteilung (MA) 18 (ed.) (2011), Siedlungsformen für die Stadterweiterung (= Werkstattberichte 115, 116). Wien, Wiener Planungswerkstatt.

Mayer V. (1993), Burgenland. Bau- und Wohnkultur im Wandel (= Mitteilungen des IGV, 21). Wien, Verlag der Österreichischen Akademie der Wissenschaften.

MAYer V. (supported by B. DASTEL) (2004), Wohnbauentwicklung und Wohnbauqualität im Umland von Wien. Ergebnisse einer Bürgermeisterbefragung. Wien, Institute of Urban and Regional Research.

ÖSTERREICHISCHE RAUMORDNUNGSKONFERENZ (ÖROK) (ed.) (2015), ÖROK-Regionalprognosen 2014-2030, Teil 1: Bevölkerung. Wien.

SCHAFFER H. et al. (2014), BAUM-Räumliches Entwicklungskonzept über die 14 österreichischen Gemeinden der Bratislava-Umland-Region. Wien, <http://www.projekt-baum.eu/de/ VismoOnline_ActionScripts/File.ashx?id_org=700029\&id_dokumenty=1115> (accessed 18 March 2016)

VitKovÁ L. (2015), Baulich-räumliche Entwicklung im Grenzraum von Bratislava von 1990 bis zur Gegenwart. In: Kapeller V., Huemer J. (eds.), Aktuelle und zukünftige Wohnbauentwicklung im Grenzgebiet Nordburgenland und Bratislava, pp. 83-93. Wien, Institute of Urban and Regional Research. 
